\title{
B113 ダブレット型粉粒体吸込みノズル入口形状に関する研究
}

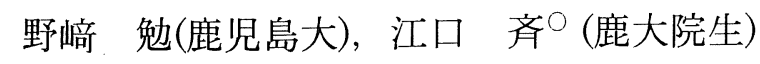

加藤 隆樹(鹿大院生), 福原 稔(鹿児島大)

\section{Study on Inlet Shape of Doublet Type Particles Suction Nozzle Tsutomu NOZAKI, OHitoshi EGUCHI, Takaki KATO, and Minoru FUKUHARA}

\begin{abstract}
It was found that higher nozzle efficiency and loading ratio are obtained by mounting the injection port at the entrance of the suction nozzle. In order to improve the efficiency of the nozzle, the entrance shape of the suction nozzle is examined by changing the radius of the edge of the nozzle, as to reduce the large separation region created at the entrance of the nozzle. Furthermore, the sub-holes are mounted at the top of the injection nozzle and wider fluidization of the particles bed could be preformed. As a result, most provable nozzle shape is decided for the given conditions.
\end{abstract}

Keywords: Multiphase flow, Solid-gas flow, Suction nozzle, Nozzle efficiency, Loading ratio, Separation

\section{1. 緒 論}

各種粉粒体の空気輸送に用いられる円形吸込みノズル と同軸上に粉粒体沈積層流動化のための吹出し流を加え た、いわゆる、ダブレット型粉粒体吸込みノズルを提案 し、これまでに、有効な管径比（=吹出し口径/吸込み 口径) が存在すること(1)や、特に通気性に乏しい粉体輸 送に詨してダブレット型ノズルは有効であること(2)など を報告してきた。これらの報告では、幾何学的形状を簡 単化したモデル、すなわち、吸込みノズル入口形状は直 裁管端面および吹出し口は単孔について一連の実験が行 われてきた。そこでは、吸込みノズル入口に形成される 大規模はく離により、吸込みノズルの有効流路面積が減 少すること、ならびに、新たに付け加えた単孔吹出し口 では、ノズル直下の鉛直方向の流動化が促進され、必ず しも有効な幾何形状ではなかった。

本報告では、ダブレット型吸込みノズルの実用モデル への一歩として、まず、吸込みノズル入口の大規模はく 離を防ぐため吸込みノズル入口端面に四分円ノズルを形 成し、その形状の流れに及ぼす影響について検討し、は く離の抑制される最小四分円半径を求める。さらに、水 力輸送で試みた吹出し口に副孔を設ける効果(3)をさら に改善するために、副孔の最適な幾何形状 (吹出し角度) についても検討する。

\section{2. 実験装置および方法}

吸込みノズル入口は流れ学上では实出管となっており、 総じて損失係数は大きい。しかし、入口端面に加工が比 較的容易な四分円形状を創製することにより、大規模は
く離を抑制し、損失係数をかなり軽減することができる はずである。この四分円の曲率半径は大きい方が損失係 数は小さくなるが、ノズルの性格上、可能な限り、曲率 半径は小さい方が望ましい。吹出しノズルの形状につい ては, 水力輸送用ダブレット型吸込みノズルの実験で, 副孔を設けることにより，改善されることが報告されて いるが, ノズルの形状にさらに工夫が必要であった。こ こでは、混合比やノズル効率等を求め、流れの可視化実 験との比較により、最適のノズル形状を検討した。

Fig. 1 に実験装置の概略を示す。混合比およびノズル 効率の評価法は前報(1) と同様である. Fig. 2 に示すよう に、直径 $100 \mathrm{~mm}$ の吸込みノズル径に対して、 $r=0,2.5$, 5，7.5 および $10 \mathrm{~mm}$ について実験を行い、ここでは, さらにノズル効率の改善を図るため, 吹出しノズルの主 孔径 (鉛直吹出し) $d=13 \mathrm{~mm}$ 一定で, $\alpha=30^{\circ}, 45^{\circ}$, $60^{\circ}$ および $75^{\circ}$ について実験を行なった。

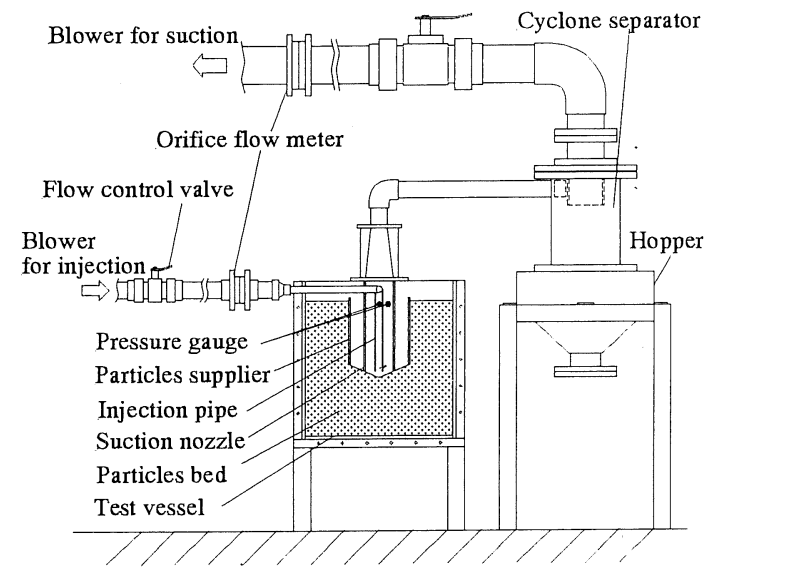

Fig. 1 Experimental apparatus 


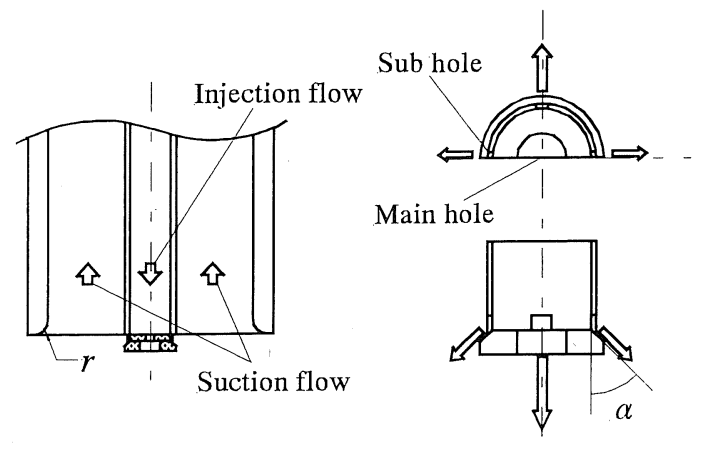

Fig. 2 Nozzle shape

\section{3. 結果及び考察}

\section{1 吸込みノズル入口形状}

Fig. 3 は混合比と吹出し流量の関係を吸込みノズル入 口形状をパラメータとして示している。図より, $r=5 \mathrm{~mm}$ 以上ではほぼ同等の混合比の改善が見られるが，後述の 可視化写真等による流れの様子を考虑し、以下の実験に おいては、 $r=7.5 \mathrm{~mm}$ を用いることとした。Fig. 4 は例 として、 $r=0 \mathrm{~mm}$ と $7.5 \mathrm{~mm}$ の場合を比較して、流れの 可視化写真を示す。この結果から、 $r=7.5 \mathrm{~mm}$ の場合、 入口部のはく離は抑制され、望ましい流れが創生されて いることがわかる。

\section{2 吹出しノズル形状}

Fig. 5 は混合比亡副孔吹出し角 $\alpha$ の関係を示している. 図より, $\alpha=60^{\circ}$ の場合が混合比は最も高い值を示して いる．Fig. 5 はこれまでの基礎実験で用いられてきた単 孔吹出しノズルと $\alpha=60^{\circ}$ の副孔を設けたノズルとを比 較した粒子流動床の可視化画像を示している. 単孔ノズ ルに比べ, 副孔を設けた場合, 広い流動領域が観測され, Fig. 5 の結果との相関性が見られる.

\section{4. 結 論}

ダブレット型吸込みノズルの性能をさらに向上するた めに、吸込みノズル入口部に形成されるはく離をなくす ために必要な最小の四分円ノズル形状を求めた。その結 果、吸込みノズル入口部にノズル径の $15 \%$ の四分円を設 けることにより、大規模はく離は抑制され、混合比やノ ズル効率に改善が見られた。さらに、粒子沈積層の流動 化を促進するために、吹出しノズルに副孔を設け、その 形状についても検討した。その結果、副孔形状について は、下方ノズル面を水平方向亡 $60^{\circ}$ の吹出し角度の場合 が最も混合比は高くなる結果が得られた。

\section{参考文献}

（1）野崎ら，粉体工学，34(1997)，400-404.

(2) 加藤ら, 日本機械学会講演論文集, No.018-1(2001), $121-122$.

（3）福原ら，日本機械学会論文集，(揭載決定).

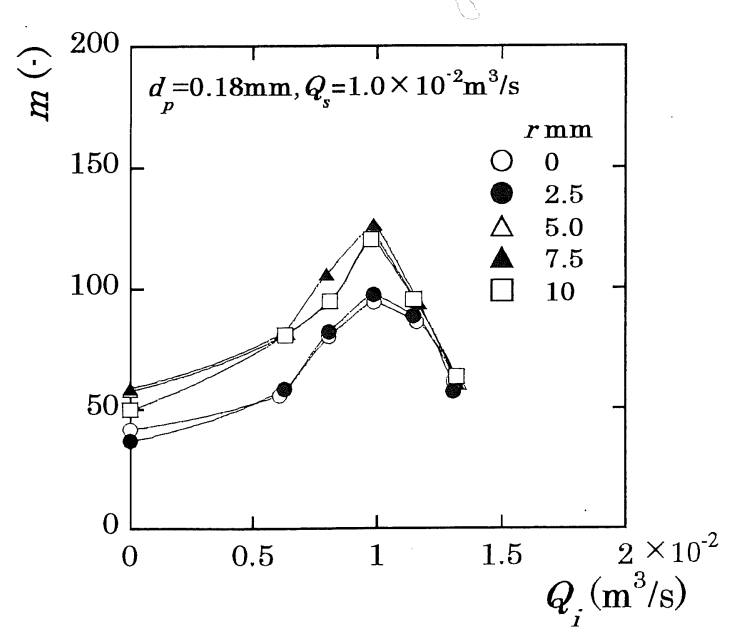

Fig. 3 Relations between loading ratio and flow rate of injection

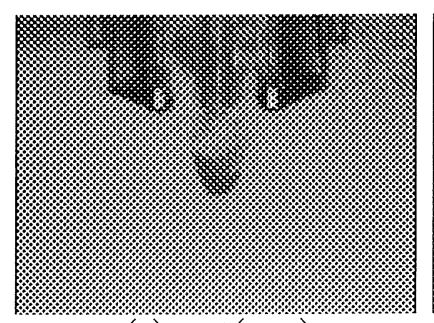

(a) $r=0(\mathrm{~mm})$

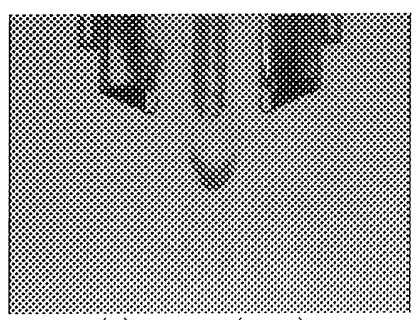

(b) $r=7.5(\mathrm{~mm})$
Fig. 4 Flow visualization of suction nozzle

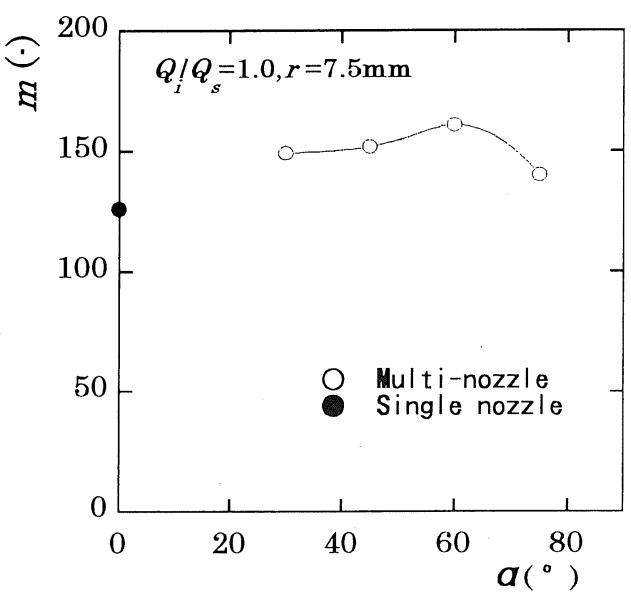

Fig. 5 Relations between loading ratio and injection angle of sub hole

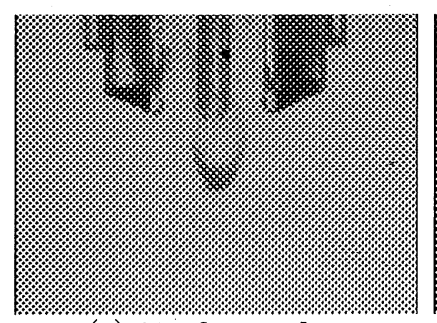

(a) Single nozzle

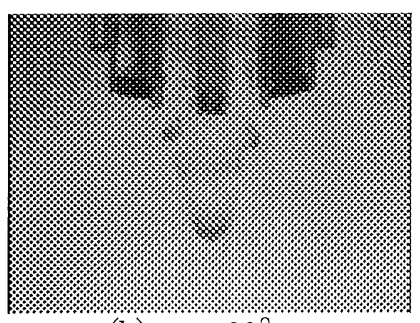

(b) $\alpha=60^{\circ}$
Fig. 6 Flow visualization of suction nozzle 